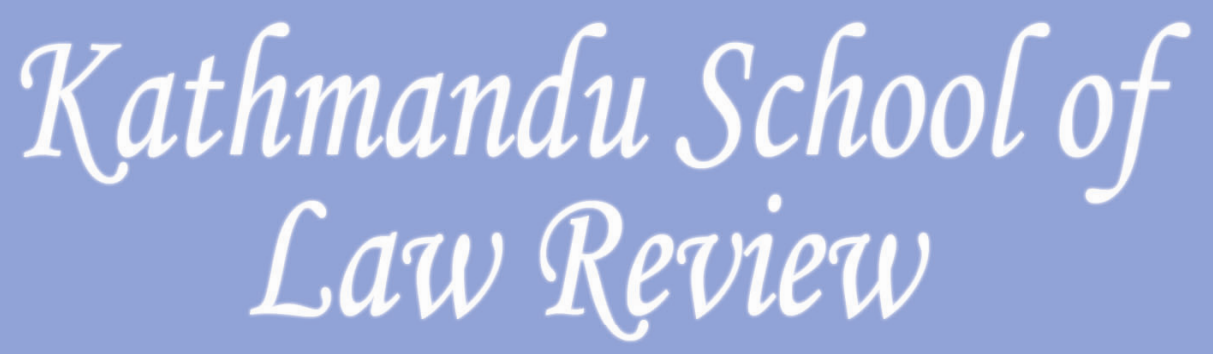

ISSN 2091-2110

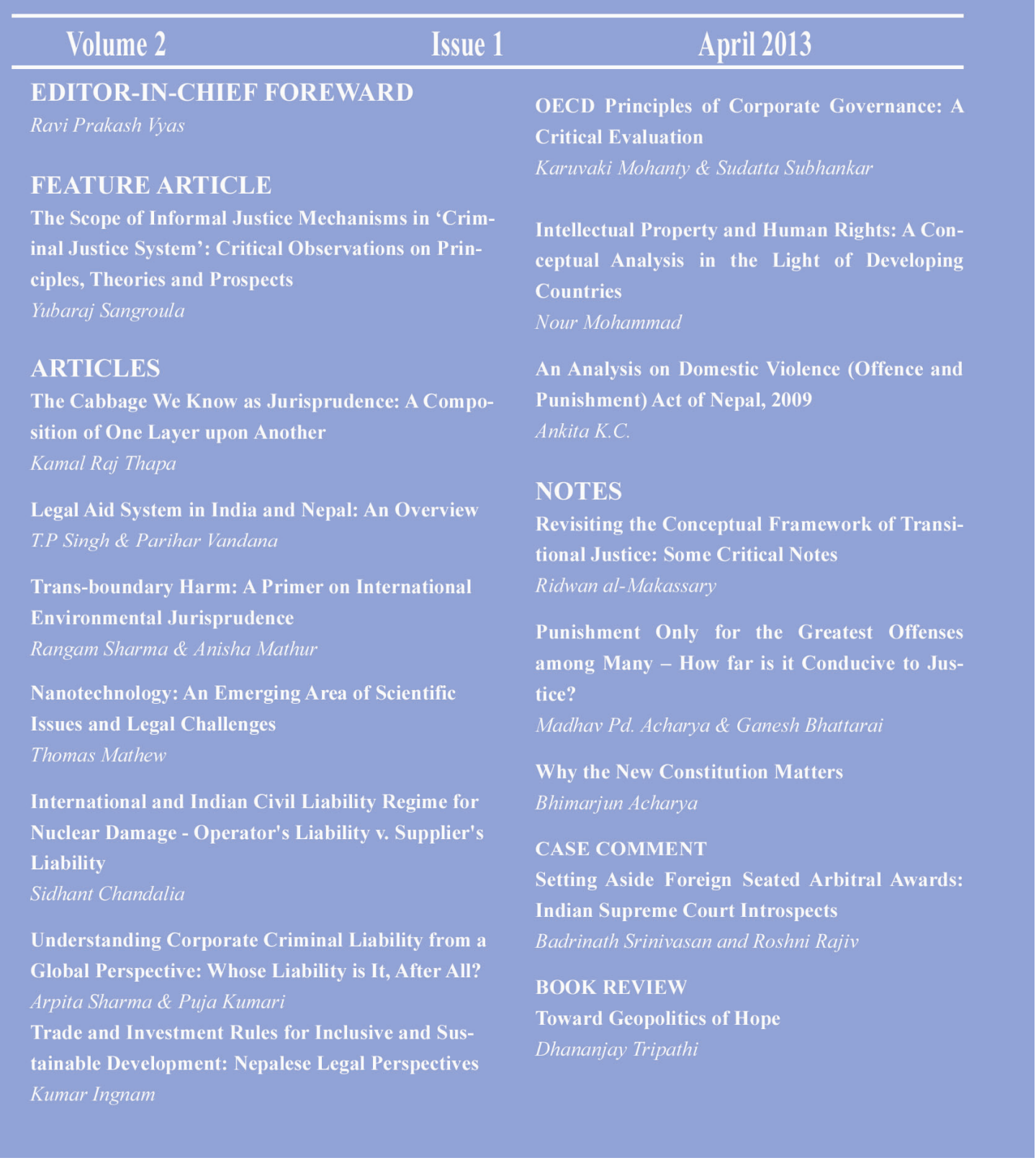




\title{
The Scope of Informal Justice Mechanisms in 'Criminal Justice System': Critical Observations on Principles, Theories and Prospects
}

\begin{abstract}
Dr. Yubaraj Sangroula
The quintessence of the paper is conception of a criminal justice system in which formal justice system and informal justice system jointly work to achieve the greater goal of ensuring security and respecting human dignity. In order to accomplish such complementarily, the conventional stereotypes on retributive, colonial and punitive approaches to the criminal justice system devoid of victimcentrality would have to be done away with. The cancerous vestiges of the colonial thinking are observable in South Asia and have eroded the faith of people upon the government and the justice system acting as a stimulus for designing an effective informal justice system, which has already been in practice since time memorial. With regards to South Asia, it is exemplified by the paralegal committee, Shalis Kendra, Union Parishad and Lok Adalat. The scope of informal justice system in criminal cases manifests in form of community mediation, plea bargaining, restorative negotiation and revocation of cases. Nevertheless, clear guidelines must be formulated to avoid potent problems in the mechanism.
\end{abstract}

\section{Introduction: Reassessing Crime and Punishment}

Criminal justice, a system of justice conventionally concerned with safeguarding the society by punishing the offenders, is a time enduring notion that is widely portrayed in the historical accounts, ballads and the works of great philosophers as a tool that state employs to quell the dissidents or recalcitrant citizens and suppress their wrongs by defining their activities as crimes. Such measures are generally perceived as coercive by the society at large ${ }^{2}$.

The belief that violence to be inflicted by a state should be proportional to the acts of offenders is a common characteristic of criminal justice system irrespective of diversity in

Ph.D. in Criminal Justice and Fair Trial; Professor In-Charge at Kathmandu School of Law, Nepal and Former Attorney General of Nepal.

2 See Jean Hampton \& Jefferie G. Murphy (eds), Forgiveness and Mercy (Cambridge University Press 1988) 111-141. 
the religious and moral beliefs and socio-political structures. ${ }^{3}$ In all societies, irrespective of the diversity of religious and moral beliefs and socio-political structures, the State's role and indulgence in criminal justice system is characterised by 'infliction of proportional violence for acts of offenders'.

Throughout the globe, criminal justice system possesses a retributive character driven by vengeance ${ }^{4}$. One of the underlying reasons could be the general perception of people towards criminals, that they are genetically felons ${ }^{5}$ and do not deserve leniency. ${ }^{6}$

This outlook towards crime and criminals has undergone substantial changes after the Renaissance $^{7}$ after which sociological theories flourished and a psycho-social approach in analysing criminality made us contemplate the possible reasons behind crimes such as our culture and family values and educational, political and law enforcement systems. At present, lex talionis notion of punishment has lost its gravity. ${ }^{8}$

3 The theory of 'reciprocity' has been the most plausible reason behind use of retribution as a tool of effective coercion underlying the criminal justice system. As put by Aristole in his, the Pythagoreans were infamous for justifying exact retaliation to crime committed by the offenders. Their reciprocity denotes lex talionis (the law of identical and direct retaliation) that is axiomatic to 'should a man suffer what he did, the right justice would be done'. See Aristotle, Nichomachean Ethics (David Ross (trs), abridgement to the original text, Oxford University Pres 1990) 30-33.

$4 \quad$ Ibid.

5 Victor Hugo's Les Misarables is a classic literature. in this regard. In a dialogue between Valjean, the main character of the novel, who is a convicted criminal turned virtuous man, and Javert, the police inspector, latter suggests that 'the leniency towards criminals cannot be considered as 'the criminals are born as criminals. In this novel, the writer has made benign efforts to demonstrate that the moral virtues is present even within hardened criminals and their transformation is possible by lessons to reignite within them the sense of moral good as a human being. The State on the other hand has persistently resisted the 'ideas of reforms and transformation of criminals into good human beings'. See Victor Hugo, Les Miserables (Norman Denny, Penguin Books 1982); the anecdote is recurrent in Fyodor Dostoevsky's Crime and Punishment. Fyodor Dostoevsky Crime and Punishment (English translation, Penguin Classics 2003); In both these remarkable literary masterpieces, crimes have been presented as outcomes of the ill-structure of the society and its failure to address the need of cohesion in interests of its members, what we at present refer as 'troubled society'.

6 Immanuel Kant has argued that retribution was the only possible justification for punishing lawbreakers. In his own words 'Judicial punishment for civil society, but instead it must in all cases be imposed on him only on the ground that he has committed a crime... He must first be found to be deserving of punishment before any consideration is given to the utility of this punishment for himself or for his fellow citizens.' Immanuel Kant, Metaphysical Elements of Justice (John Ladd trs, $2^{\text {nd }}$ edn, Hackett Publishing1999) 138.

7 Les Miserable's description of the France after revolution pierces the heart. Similar depiction of the Russian society of the time is found in Crime and Punishment. The social wretch and its consequence is depicted in such a way that the main character of the novel moves out with a hallucinating a utopia to fix the societal wrongs by killing oppressor, a lady who pawns things to exploit poor and needy. A law student, the main character of the novel, who has undergone acute depression because of wants and ensuing frustration and darkness of future that causes harms to his vanity, commits a gruesome crime with a belief that killing a person with loathsome qualities and characters, is simply a killing of principle that hinders society to flourish justice. He thinks killing such a person can never be a crime because it is a revolution. Hugo (n 5) 326; Dostoyevsky (n 5).

8 Hampton and Murphey (n 2). 
Emotions such as greed, anger, jealousy, revenge, or pride aggravate person's susceptibility to fall in sphere of crime. The frequency and accomplishments of crimes teach persons the art of committing crimes. Hence, some people decide on committing one and carefully plan in advance in order to increase gain and decrease risk. Many studies over the last decades have quite distinctly reflected the behavioural choices of people in which some even consider a life of crime better than a regular job, believing crime brings in greater fortune of both the wealth and power. Others get an adrenaline rush when successfully carrying out a dangerous crime. Some others commit crimes on impulse, out of rage or fear. In the context of these new findings and development, the criminal justice systems along with attitudes of societies towards criminals changed significantly. The American society played a pioneer role in this change. ${ }^{9}$

In most of the developing countries, the criminal justice system evolved customarily. The moral aspect of the crime received empathy from the system, which required stringent enforcement of law and strict penalty. For instance, most of countries in South Asia practiced a kind of rudimentary inquisitorial system which invariably required accused to prove innocence, prior to establishment of colonial regime ${ }^{10}$ Even China practiced the inquisitorial system. ${ }^{11}$ The early Chinese criminal justice inculcated lex taliones in most severe fashion. Some references show that early Zhou dynasty practiced a penal system of 'death for death', and the criminal liability encompassed the entire family of the offender.

9 In the 1950 s and 1960s, the American society came to encounter social issues unprecedentedly. The status qou got challenged by the emerging tide of civil rights movement and the crime rates also soared up which, in turn, pressed the US Government to ponder upon the rising trend of the breakdown of the status quo and ensuing challenges. The US Government hence came out with added focus on the "need of studies on causes of crimes followed by policies and laws on crime control. Warren Court's (it refers to the US Supreme Court between 1953-69, when Earl Warren served as Chief Justice leading a liberal majority and used the judicial power in dramatic fashion) contribution is significant in this regard. It issued a series of rulings which redefined citizens' rights and substantially altered the powers of police and courts. It expanded civil rights, liberties, judicial power and federal jurisdiction and invalidated school segregation (Brown v. Board of Education), protected freedom of speech (Brandenburg v. Ohio), stroked down poll taxes (Harper v. Board of Elections), necesssitated one person one vote system (Reynolds v. Sims), and protected accused against police abuse (Miranda $v$. Arizona). These new developments brought a sweeping change in the notion of governance and criminal justice system. The decision in Miranda $v$. Arizona ended the conventional stereotypical attitude of police and courts regarding 'integrity of suspect or accused. The criminal justice system thus acquired the new rails for sliding ahead. See (for detailed discourse) Cass Sunstien, 'Breyer's Democratic Pragmatism' (2006) 115 Yale Law Journal 1719, 1721-1722.

10 Nepal, for instance, promulgated the ever first code of laws in 1336, named Manabnyaysastra (Code of Human Justice- a system of law and justice to be carried out by human authorities). The code presented a notion of tougher penal system. Similar to Western societies, it resorted to the model of lex taliones. Hence, the offender received the same harm he/she had inflicted on the victim. Most importantly, the accused had to prove his innocence. See Center for Legal Research and Resource Development (CeLRRd), Baseline Survey on Criminal Justice System of Nepal (CeLRRd 2002).

11 Zeng Ge, 'What Kind of Party? The Role of Crime Victims in Chinese Criminal Procedure' (2008) 38 Hong Kong Law Journal 493. 
Most Asian countries have witnessed an unprecedented economic and social upsurge over the last some decades. Sadly, less improved and less modernized fashion lurk into the system of criminal justice. While most countries in Asia have ratified international human rights bill, the standard of the criminal justice system far from meeting the threshold of fair trial. The prevailing criminal justice systems of Asia possess some common aspects: ${ }^{12}$ (a) the procedures are staggeringly lengthy and time consuming thus protracting trial tediously longer time ${ }^{13}$; (b) most of the accused come are rural or shanty urban youth generally from those communities that are abjectly marginalized in terms of development opportunities ${ }^{14}$; (c) overwhelmingly proportion of accused and offenders has weak educational background; ${ }^{15}$ and (d) the poor and marginalized communities suffer most acutely from the prevailing crime patterns.

\section{Crimes and Criminal Justice System in Developing Countries: The Question of Human Dignity and Security}

The relevance of the formal system of criminal justice' is widely suspected, at least in the context of developing countries of South Asia as it suffers from myriads of problems. The lack of trust of people on 'fairness and objectivity of the investigation, prosecution and adjudication' is incredibly deep. Clever offenders seldom feel deterred by the system

12 A study by CelRRd reveals that Nepal is fully pauperized and alienated. Further, the justice system is considered to be a strictly formal sector, hence the rules are considered sacrosanct. These outlooks obviously push the sector of justice in the shadow of development endeavors. See CelRRd, Research Report on Trial Court System in Nepal (CelRRd 2002); A UN study on crime trends reveals a 'very sorry state of affairs in the sector of justice in Asia'. The ratio of police personnel (in population of 100,000) in South and South East Asia, including China, is 202 and 299 respectively. The ratio of prosecutors and judges in both regions is 2.5 persons per one hundred thousand populations, whereas this ratio is 10 and 8.6 persons in one hundred thousand in USA. See UN Office on Drugs and Crimes, International Statistics on Crime and Justice (HEUNI Publication 2009).

13 The delay in criminal proceeding leaves accused languishing in prison for waiting date for trial. On the other hand, the victims are deprived of justice as the trial is a never ending process. Waiting for judgment of the court, the victims of crimes have to spend years with nothing at hands. The reparation or complementation too becomes a matter of illusion. Eventually, the victims of crimes have nothing at hand but to forget the painful past and the accused is simply locked up and forgotten. In Nepal, over 14000 people are incarcerated in prisons having total capacity to accommodate 11000 inmates. There are dilapidated buildings with no basic facilities. In India and Bangladesh, over 300,000 and 75, 000 accused respectively, are waiting for trial for over a long period of time. Many of them are simply forgotten. The pathetic situation appears when 'most of these accused are acquitted by the when after a long wait for trial. The ratio prosecution success in Nepal, India, and Bangladesh is less than 50 percent. It means that either the acquitted 50 percent are able to tweak the course of justice or they are victims of human rights violation. In any of the case, this is a miscarriage of justice. 'Locked up and Forgotten', Conference on Penal Reform in Developing Countries, 6-7 October 2010, Dhaka.

14 A survey by CelRRd reveals that over 90 percent of prisoners poor with negligible literacy. Most prisoners have committed crimes under pressure of desperate want. A considerable number of such prisoners were found involved in crime of human trafficking, logging and trafficking of drugs. Those who were found guilty of committing crimes of trafficking girls and women for prostitution had victimized another poor person who too was poor and deprived. CeLRRd, Survey on Accessibility to Legal Aid (CelRRd 2010).

Ibid. 
whereas innocents think their lives would be irreparably destroyed once they are fallen in hands of the system. The prisons of the South Asians are overcrowded by those waiting for trial. The prisons lack even the minimum facilities, and even those rare supplies are shared by implausibly huge number of inmates. ${ }^{16}$

The investigation of crimes is inefficient, ineffective and marred by subjective and coercive elements. The practice of arrest is random, often involving use of force and the interrogation is torturous and humiliating and extended for incredibly longer period of time. The practice of intimidation and torture of during detention in varying degree is common. The police officers often defend such practice as a necessary tool for revealing truth about crime. The prosecution is less attentive to facts and less sensitive to rights of accused as well as interests of victims. The prosecution is hardly critical to evidences procured by the investigators. This is one of the major factors for the clogging of courts. The system is cancerously defiled corruption. ${ }^{17}$ The quality of defence is constricted, unreliable and to add to the misery of the poor, unaffordable. The lawyers' ethical standard in South Asian nation is questionable. The public views lawyers as professionals who are skilful in contortion and manipulation of facts. The underrepresentation in terms of quality is thus a widely felt lacuna of the defence professionalism in South Asian nations. The abuse of power by criminal justice actors, often occurring as an outcome of insensitivity to human dignity and rights of people transfigures the values and norms of justice into a mockery.

\section{The Legacies of Colonial Culture and Their Impacts}

Many problems of criminal justice system in South Asian countries are handed down by the colonial culture of coercive enforcement of criminal laws and hierarchical bureaucratic notion of actors. ${ }^{18}$ The so-called colonial culture overlooked the 'human element' of the system as it emphatically put stress on 'power element' of the system. Consequently, the need of harsh law is perceivably deeply rooted in South Asian rulers' mindset who demand sweeping law on prerogatives or immunity for criminal justice agencies for ignoring compliance or observance of due process of law during investigation, prosecution and adjudication. $^{19}$

16 India has the largest number of prison-population. About 300,000 people are incarcerated in jails of India and significant number of these inmates are waiting for trial condition. As reported by the Ministry of Law and Justice in 2010, over 92, 000 prisoners waiting for trial condition were set free by end of April 2010. It was said that another 1, 10,000 inmates were supposed to be freed by the end of July 2010. The scenario is self evident of the state of criminal justice system. 'Government: Enabling the Governance' (Online Information Service, 2010) <http://www.igovernment.in> accessed 29 April 2013.

17 'Weak Criminal Justice Encourages Corruption' is a statement of the Ashwani Kumar, the Chief of the Central Bureau of Investigation (India). 'Statement of Ashwani Kumar' (Indianexpress).

$<$ http://www.Indianexpress.com> accessed 29 April 2013.

18 See Anupama Rao \& Steven Perce, Discipline and the Other Body: Humanitarianism, Violence and Colonial Exception (Duke University Press 2006).

19 During the Maoist insurgency, the government enacted Terrorist and Disruptive Activities Control Act 2002.The Act gave sweeping authorities for Police to arrest, detain and interrogate suspects. The 
South Asia has traditionally been ruled by a system of criminal laws devised to protect the the colonial or autocratic regimes. The Ranas in Nepal ${ }^{20}$ and the British ${ }^{21}$ in Sri-Lanka and India, including Pakistan and Bangladesh, used criminal laws only as means of 'crime control and safeguard of regressive status quo. The framework of the criminal justice system was structured in a way to give special role to the police. Hence, in all South Asian countries the patrolling police were also entrusted with the responsibility of crime investigation. The criminal justice system thus essentially held a punitive character. This autocratic, colonial and punitive form of system has played crucial role in legitimizing the following practices of the law enforcement agencies in South Asia:

a. The suspect is systematically condemned from the time of arrest and is conspicuously subjected to a state in which he/she has been rendered unable to enjoy the rights normally available to all human beings. He/she is psychologically intimidated. Risk of being treated physically violently looms large.

b. The participation of the victim is almost nonexistent His/her mere responsibility is to appear in the court for testimony. Both the investigators and prosecutors are unconcerned to the 'safety and security' of the victims. The presence of victims along with the charge sheet in the court is considered not essential. Hence, the victims of crimes even are not aware of the charges imposed on the accused. If the charges imposed by the prosecution fail to sustain in the court, the prosecutor enjoys exclusive authority to seek or abstain from seeking such remedy from higher

authority included 'power to detain person for uncertain period of time' without judicial process or charge. Similarly, in the aftermath of the terrorist attacks of September 11, 2001 and the attacks soon thereafter on the Jammu \& Kashmir Assembly and the Indian Parliament buildings, the government of India enacted the sweeping law namely, the Prevention of Terrorism Act 2002. Bangladesh introduced a similar law empowering the police to take rapid actions against criminals. Sri-Lanka has stricter law and Pakistan is not an exception. All these hard laws provide sweeping powers to the officers to arrest detain and interrogate suspects and charge them with crimes as per their wishes.

20 The Ranas represent a system of oligarchy, a rare practice, in any part of the world of holding the post of prime minister in hereditary line. They ruled Nepal, in backing of the British in India. While the monarchy continued, it was put in a palace as a titular institution; it wielded no powers at all. The first Rana ruler Janga Bahadur was inspired to introduce a Napoleon Code-like law in Nepal, and thus he promulgated in 1854 a code popularly known as Muluki Ain (General Code). The Muluki Ain derived a number of principles and rules from the Napoleon Code. As a matter of fact, Nepal introduced a civil law system while India, under the British was ruled by common law system. The Muluki Ain also encapsulated the historically developed rules of laws and values concerning criminal justice which was equivalent of medieval inquisitorial system in Europe. The Muluki Ain adopted a punitive approach and methods in arrest, detention, interrogation and trial. It ended the practice of plea bargaining Nepal historically used and formally legitimized the 'torture'.

21 Though British used common law and discarded practice of 'extra-judicial' confession as evidence for conviction, torture was used extensively to extract confession from natives (Indians) who were viewed as being accustomed to such practices under pre-colonial regime. Torture was used in not merely sporadic incidents of crimes. It was rather a policy pursuit of the colonial administrators. They viewed that the native population was uncivilized and the use of force was necessary to make them behave as proper colonial subject'. Rao \& Perce (n 18) 5, 26. 
authority of the court. The government is not obligated to seek approval of the victim to remove the case or withdraw the charge.

c. The system of accountability of actors the system is fully in disarray. The psychology underlying the given attitude is that 'the failure or success' of trial has nothing to do with victims because the 'criminal justice system is a prerogative of the state'. This dire lack of accountability has irreparably been 'fostering a condition of miscarriage of justice because the state of 'having no accountability promotes corruption' in the system. The lack of accountability and ensuing consequences such as corruption and miscarriage of justice are attributable to the people's swelling misgivings or lack of confidence to the system.

d. Bureaucratization of the system of criminal justice, often marked by the red-tapism, under-table kick-backs, favouritism and nepotism, is a well-entrenched character of the criminal justice system in South Asia. The huge backlog of the cases in South Asian courts is attributable to this factor. The backlog is condition of 'jamming' of the court procedures or judicial procedures. ${ }^{22}$

e. The perception that criminal justice system is a prerogative of the Government hence it possesses unrestricted privilege to prosecute or refrain from prosecuting the crime has engendered a culture of impunity in South Asia. In Nepal, for instance, over the last few years, the Government has withdrawn hundreds of cases from prosecution claiming that they were of political nature'. ${ }^{23}$ In India, thousands of accused and convicted persons are freed in the pretension of addressing the congestion problem of the prison. ${ }^{24}$

f. Another erroneous perception that the crime investigation is a privilege of the police department is prominent. This notion has been continued as an underlying 'notion' of the criminal justice regime in South Asia. Hence, arrest, detention and interrogation are considered as 'powers' of police authorities. Torture and inhuman treatment thus sprout out of this perception about criminal justice system. The police use sweeping powers during investigation of the crime. ${ }^{25}$

22 A joint study by CeLRRd and DIHR (then DCHR) reveals that about $50 \%$ of cases would be in backlog every year in Nepal. However, as pointed out by the research the percentage of cases backlogged over a period of three years was a smaller, or we can say negligible. See CeLRRd \& DIHR, The Comprehensive Analysis and Reforms of Criminal Justice System of Nepal-1999 (CeLRRd, DIHR 1999); The problem of backlog and 'in-wait for trial' condition in Indian and Bangladesh is extreme. See Malimath Committee, Malimath Report (2003).

23 The new Government led by Dr. Baburam Bhattarai executed removal of 650 criminal cases, some of them included rape and cold-blooded murder. See United Nations Human Rights Commission (UNHCR), Remedies and Rights Revoked (June 2011).

$24 \quad$ Malimath Report (n 22).

25 See Yubaraj Sangroula, 'Professional Relationship between Crime Investigators and Prosecutors in the Human Trafficking Crimes'(2012) 1 Kathmandu School of Law Review 12 , 12-33 
The above discourse plainly reflects that the prevailing criminal justice system in South Asia is not capable of imparting sense of human dignity and security with regards to both the victims of crimes and offenders. The criminal justice system in this part of the globe is largely ritualistic and relics of the past colonial and feudal structure of the society.

\section{Grounds for Skepticism on the Capability of the Criminal Justice System of the Developed Societies to Preserve Human Dignity and Security}

The proportion of criminals is larger in developed countries despite their well-defined laws and rules of procedure, institutions of criminal justice, mechanisms of accountability, system reinforcing accountability and human rights, availability of the modern science and technology aiding crime prevention and investigation and most importantly, prevention of corruption. Whether development foster crimes, is yet unanswered. However, one can argue on account of the given scenarios that the prevailing structure of the criminal justice system has failed to be a desired mechanism to discourage crimes in any part of the globe. Moreover, the adversarial principles of the contemporary criminal justice system have failed to satisfy the concerns of the victims of crimes.

Let us observe the statement of Mariano Florentino Cuellar, professor and dean of the Stanford Law School:

Etched into the public mindset is a familiar bundle of ideas about criminal law. At its core is the premise that criminal sanctions are exceptional punishments, categorically distinguishable in application from civil penalties, and used primarily against people harming society by causing violence or severe injury to identifiable victims. Although this model is astonishingly persistent, nearly every aspect of it is open to question. Casting aside distinctions that pivot on the presence of identifiable victims or harms rather than risks, the American regulatory state is heavily dependent on-if not addicted to-criminal enforcement. As its economy, population, and bureaucratic capacity have grown over two centuries, the United States has achieved the largest prison population in human history, with its imprisonment rate the highest in the industrialized world. ${ }^{26}$

The message of the statement is obvious. It has distinctly articulated the following: a) the perception that the criminal justice system of exceptional punishment system has not left the mindset of the citizens of the developed nations; b) the attitude that the criminal justice system is concerned with prevention of violence is still pervasive in the developed nations; c) the effectiveness of the criminal justice system in dealing with the crimes is open to criticism; and (d) the criminal justice system's counter-productivity can be seen in the largest prison population in USA.

26 Mariano-Florentino Cuéllar, 'The Political Economies of Criminal Justice' (2008) 75 University of Chicago Law Review 941, 941. 
The crime ratio in developed countries has unprecedentedly increased along with growth of economy and progress of industries and infrastructure, the US leading in this regard. ${ }^{27}$ Along with the unprecedented rise of crimes and prison population, the empire of the criminal justice system has become as broad as it has been exceedingly harsh in its effects. As rightly observed by Mariano, 'every year over a million people face arrest for drug possession and hundreds of thousands them are prosecuted for drug, weapons and immigration violations. ${ }^{28}$ As a matter of fact, the developed countries seemingly tend to become a system of 'governance through crimes'. ${ }^{29}$ It seems that the entire business of the government is to enforce the criminal laws. ${ }^{30}$

\section{Harms of Crimes and Redress Provided by the Criminal Justice System}

Harms of crimes are not easy to assess. ${ }^{31}$ While every crime imposes some kind of harms in the society in several distinct ways, the analysis of the costs, particularly in quantified way proves to be difficult. The cost arising out of damage of the property, destruction, or theft can be measured as loss in the market values. Similarly, other costs such as loss of the future income resulting out of physical disability or the destruction of the business property or manufacturing equipments can be assessed, though subjectively. But there are several other forms of costs of crimes which prove difficult to quantify. But many of such costs cannot, or should not be, quantified if the damage or loss is to be meaningfully or objectively assessed. Such losses or damages are directly associated with the value system or norms of the society which are pre-conditions for peace, stability and progress of the society. The cost of crimes in society needs to be assessed against its implications in the society at large.

Discourse on what harms criminal justice system is expected to redress, is very scant. The general or ordinary people think the main agenda of the criminal justice system is to insure safety of the society thorough: a) deterring the potential offenders by punishing the offenders of the crimes, and (b) building a trust that the violence committed by the crimes would be redressed by rehabilitating the victims or repairing the costs of crimes. This notion of criminal justice system demands prosecution of offenders for punishments that may serve the mental satisfaction of the victims will not redress the losses sustained by the

27 See James Vicini, 'Number of US Prisoners Has Biggest Rise in Six Years', Reuters, 27 June 2007 <http://www.reuters.com/article/domesticNews/idUSN263705312007627> accessed 28 April 2013.

28 Cuéllar (n 26) 942.

29 See generally Jonathan Simon, Governing Through Crime: How the War on Crime Transformed American Democracy and Created a Culture of Fear (Oxford University Press 2007).

30 UNODC, 'The 2012 United Nations Survey of Crime Trend and Operations of Criminal Justice System' (UNODC , 2012) <http://www,unodc.org/unodc/en/data-and-analysis.crimedata.html> accessed 28 April 2013.

31 See Scott M. Noveck, 'Testing the Theory of Rational Crimes with United States Data 1994-2002', Inter University Consortium for Political and Social Research Bulletin, Institute for Social Research, University of Michigan, 2006-2008. 
victims. The insensitivity of the system to the latter aspect is phenomenal and has been a serious cause for declining trust of the people.

Crimes impose several costs to the society. While the pecuniary costs might be easily measured and redressed, there are some implicit or intangible costs which may disastrously affect the society. In violent crimes such as murder, for instance, the harms of crime do not confine to economic loss, rather, include injury to the value placed by the society on life itself. $^{32}$ The impact of some other violent crimes such as rape may be far more devastating on the entire psyche of the society.

Crimes encourage illegal market and economy. The growth of criminal activities attracts investment in non-productive and non-social redevelopment activities. It creates a vicious cycle of 'increasing criminal affairs and growth of illegal markets'. The eventual impact is fallen in the entire 'regime of the governance and development'. ${ }^{33}$ The economic analysis of crimes shows that 'the growth of crimes is an intrusion in legitimate rights of people to participate in fair economic entrepreneurship'. ${ }^{34}$ The growth of crimes and resultant costs demand additional police personnel in order to monitor criminals' behaviours and investigation the crimes and judiciary is required to adjudicate the offenders. The correction and prison systems are equally essential. Together, all these institutions and their activities consume a huge shared of public revenues thus the burden on national exchequer posed by crimes is huge.

\section{Rethinking the Conventional Model of Criminal Justice System}

The foregoing discussion presents some insights on the necessity of rethinking the prevailing model of the criminal justice system. The discussion has made attempt to reflect on problems of the conventional criminal justice system and attitudes of the people and government attached thereto:

Reorientation on values of priorities and functions of criminal justice system: A system of justice whether be it civil or criminal, is thus inseparably linked up with the governance system and development objectives. The 'threshold condition' of development demand

32 Gary S. Becker, 'Crime and Punishment: An Economic Approach' (1968) 76 Journal of Political Economy 169, 169-217.

33 Isaac Ehrlich, 'Participation in Illegitimate Activities: A Theoretical and Empirical Investigation'(1973) 81 Journal of Political Economy 551, 551-767.

34 Ehrlich has made attempt to depict the overall impacts of crimes on market. Through his research, he has identified losses due to socially inefficient investment by criminals in the course of criminal activity. He says, 'For instance, the time that criminals spend engaged in criminal activities rather than legal occupations results in a loss of potential production, which is essentially an opportunity cost of crime to society. Because criminal activities are inherently non-market activities, the "wages" from crime are not priced at the market rate, which obstructs the efficient allocation of labour. Ehrlich also points to socially wasteful expenditure by criminals in order to protect against prosecution, including any resources a criminal uses to cover his tracks and all fees paid to defence attorneys to try and avoid conviction'. Ibid. 
guarantees of the five basic rights to every individual. They are: a) non-violability of the physical integrity of person, irrespective of socio-economic and gender diversities; b) nonviolability of personhood of individual, irrespective of age, physical condition and professional engagement or capacity; c) non-intrusion in basic liberties and freedom of choice; d) access to basic supplies, minimum education being the fundamental one, and e) access to participation in economic entrepreneurship.

The material conditions of a given society, undeniably, but perceivably, have bearings on its system of justice and this theory implicitly rejects the view that the system of justice has universally applicable value. Injustice perpetrated by common individuals or state's authorities should be criminalized and penalized. ${ }^{35}$

Development paradigm of criminal justice system: In developing countries, the term 'development' of society' refers to a 'state of realization of the minimum threshold condition of progress by members of the society. Economically, the term development refers to a state of adequacy of resources and opportunities necessary for achieving the projected goals of life, at least the attainment of the minimum threshold condition. Politically, it connotes a state in which people are able to freely and fairly participate in decision making process of the State. The indispensability of connection, or roughly speaking the nexus, between system of justice and development is thus obvious.

In this paradigm, human security is a primary thrust of the criminal justice system, in the lieu of which, criminal law should be defined as an instrument of protecting human dignity and welfare, rejecting the significance of theories that define justice as an abstract or metarealist concept. ${ }^{36}$ Economic and social needs constitute the primary sources of values or norms for 'meaningful operation of the system of justice. The positive rules of law are thus instrumental in recognizing, protecting and enforcing the values and norms recognized by

35. The particle of violence by communities against couples engaged in inter-caste marriage in India, Bangladesh and Nepal is still a serious problem. Occasionally, the spouses are forced out of the community, and sometimes physically assaulted. The government authorities, the police officers in particular, seem to be less interested to intervene in such situation. The criminal justice system in such a situation remains not only dormant but may be used against the victims. While it is typical case of abuse of power, the criminal justice system finds no mechanism to enforce against such authorities. In Khanchanpur district, one of the southern plain districts of Nepal, a married inter-caste couple was removed off the village. When they returned to visit their sick grandmother, they were physically assaulted and seriously wounded. The police officer of the district declined to register FIR and take action against perpetrators until a legal action was proposed by the Office of the Attorney General. It implies that the enforcement mechanisms of the criminal justice system in traditional developing societies need to be considered in view of the reality of the society.

36 The legitimacy of a rule of law is determined by its accomplishment of protecting individual's physical integrity, ensuring security of person, safeguarding freedom of choice and action, promoting capacity of acquiring knowledge and furthering participation in economic activities. These indicators determining the legitimacy of a rule of law constitute a 'regime of justice. A law violating one or other of these indicators is considered unjust law. Only a just law can secure justice. Thus, the term 'justice, conceptually, is an instrument of securing just or rational quality of law. See Brian H. Bix, 'Joseph Raz and Conceptual Analysis' (2007) 6(2) Philosphy and Law (APA Newsletter) Spring, 1-7. 
the principles of justice. This notion of justice provides normative grounds for the application of the concept of rule of law.

This thesis underscores that the equity-based distribution of advantages, the economic and social development programs and progressive legal culture are coherently interacting components of modern and pro-human rights criminal justice system. The progressive legal culture embodies human rights laws and values as cardinal principles of human security and dignity' The relationship between human rights and criminal justice system is thus indispensable. However, the enforcement of human rights through a criminal justice system requires a sound political stability, economic development and good governance. A long list of economists, legal scholars and development agencies from Max Weber and Douglas North to the World Bank have argued that rule of law based justice system is necessary for sustained economic growth and well-functioning of democracy. ${ }^{37}$

\section{Agenda of Notional as well as Structural Reforms in Criminal Justice System}

Building competency of criminal justice system to address 'the problems of impunity, increasing threat of crimes to the security social structure, wider lacking of the accessibility of poor to the mechanisms of criminal procedure and redemption of the harms of crimes sustained by victims should be considered as the primary thrust of the reform agenda of the criminal justice system. The theoretical discourses above amply shed light on dimensions and the causes of the criminal justice system's failure in the modern era. Nonetheless, it would be appropriate here to summarise some those vital notions and causes of failure in order to help "properly reflect on agenda of reform or improvement required.

a. When crime enters purview of the system, it becomes monopolized 'providence and duty' of the judicial authorities. ${ }^{38}$ The operation of the criminal justice system is rendered confined to the public sector as an agency of State to impose punishment. Traditionally, crime is reconsidered a public matter and only the State has right to prosecute and punish the offender. This notion of the criminal justice system has proved to be a serious constraint in its effective enforcement.

b. Crime against victim is considered an offence against society and eventually the State. ${ }^{39}$ But at present, punishment to the offenders, for his or her offence, is regarded to be just and the victim has no rights but to concede with the decision of the State. The reparation of the harms meted out by the victim is forgotten.

37 See Randall Peerenboom, 'Human Rights and Rule of Law: What is the Relationship?' University of California Los Angles School of Law, Public Law \& Legal Theory Research Paper Series Research Paper no. 05-31/2005.

38 Zeng Ge, 'Which Kind of Party? Role of Role of Victim In Chinese Criminal Procedure' (2008) 38 Hong Kong Journal 493, 493.

39 See Alline Pedra, Jorge Birol \& Arno Dal Ri Junior, 'The Role of Organized in Informal Justice Systems: Brazilian Case'(2011) 2(1) International Journal of Security and Terrorism 59, 59-80. 
c. The institution of criminal justice has become an expensive enterprise. Neither the victim nor the accused have no adequate resources and cannot afford hiring lawyers for sophisticated intellectual game of win and loss. ${ }^{40}$ The criminal trial in adversarial system is a competitive game between public prosecutor and defence lawyer. ${ }^{41}$ The confidence of the victim of crime over the system has thus seriously eroded. The wealthy offender is defended by most brilliant lawyer and the victim by the prosecutor, whose main interest is to secure the punitive obligation of the accused for the interest of the State. The interest of victims is nobody's concern or affair. Neither has the victims been properly represented nor have they received space or mechanism to defend themselves. ${ }^{42}$

d. The criminal justice systems of most developing countries suffer from crisis of confidence of people. The lack of credibility in police, prosecutors and judges as well as difficulties to reach police stations, lack of knowledge concerning the niceties of justice system, lack of resources to pay for lawyer, lack of state attorneys to guarantee for deprived people's rights and huge length proceeding are some entrenched problems tainting the system. These problems appear to disregard that 'access to justice and due process of reparation of harms meted out of crimes' is indispensably basic human rights against government. ${ }^{43}$

e. In most of the traditional developing societies, the formal structure of the administration of justice has never had full control over the system dispute or conflict resolution. In such societies, the system of local governance, security and means of dispute resolution are provided through non-state institutions. In such societies, the relation between formal and non-state institutions may remain contradictory as well as mutually reinforcing. Mostly in societies comprising of diverse tribal or ethnic communities, the formal system of criminal justice is neither fully accepted nor confided with. In such societies, the importance of informal or non-state institutions in resolving disputes is always paramount. In Afghanistan, for instance, 80-90 percent civil disputes and criminal offences are dealt with via informal institutions. ${ }^{44}$

$40 \quad$ Ibid.

41 See Gabriel Hallevy, 'Is ADR Alternative Dispute Resolution) Philosophy Relevant to Criminal Justice? Plea Bargains as Mediation Process between the Accused and the Prosecution' (2009) 5(1) Original Law Review, 4-5.

42 Pedra, Birol \& Ri Junior (n 39).

43 According to Hofeld's theory of rights, claim-rights require duty bearers for enforcement. As rightly pointed out by Prof. Laurence H., the victims owe claims against the government. In his statement to Senate Judicial Committee, Laurence opined that 'rather it is the government authorities themselves, those who pursue (or release) the accused or convicted criminal with insufficient attention to the concerns of the victim, who are sometimes guilty of kinds of violation that properly drawn amendment would prohibit'. See Senate Judiciary Committee, Proposed Constitutional Amendment to Protect Victims of Crimes (Statement of Laurence H. Tribe, $05^{\text {th }}$ Congress $1^{\text {st }}$ Session, 1997).

44 See 'Linkages between State and Non-State Justice System in Eastern Afghanistan (A Survey Report)' (The Liason Office, 2009) 5 <www.usip.org/files/ROL/state-and-non-state-justice> accessed 28 April 2013. 
f. Overcrowding of State judicial institutions is a serious problem in most developing countries. The service provided by state judicial institutions is driven by excess of formalism, which makes the system not only accessible for also lengthy and cumbersome to follow. Problems drive people to seek justice informally. The developing societies are thus supposed to understand these exigencies of the dispute resolution.

Need of restructuring the formal system of Criminal Justice to accommodate informal procedures and mechanisms of conflict resolution: The problems discussed above call for a fresh considerations' on norms, theories, principles and mechanisms of criminal justice system. It is plain from the discussion above that 'the rate of crime is increasing both in developing and developed countries, severely affecting the social structure as well the political and economic institutions'. Crimes have become costly in terms of governmental expenditure as well as harms sustained by victims. The remedy however, is seen neither effective nor efficient. The confidence of people over the system significantly has eroded and, unfortunately the organized criminal gangs are taking over the roles to deliver justice. The modern criminal justice system has to be able to seriously revisit its theories, principles and mechanism.

\section{Is Alternative Dispute Resolution Philosophy Relevant to the Criminal Justice?}

The answer is positive, although the reluctance on the part of State institutions and considerably larger part of the civil society is massive. Nonetheless, there is scope for application of informal procedures or mechanisms in criminal justice, albeit they are not easier to invoke. The following norms and principles of criminal justice system, the adversarial system in particular could be relevant in application of alternative dispute resolution philosophy for settlement of conflicts of criminal nature:

a. In adversarial (Anglo-American model in specific) model of criminal justice, the hearing of cases takes the form of legal confrontation between parties involved in the case. ${ }^{45}$ The court in this system is simply obliged to decide between their respective arguments. The court does not assume role of discovering evidences. The parties are obliged to discharge the burden of proof for their pleas or claims. As a matter of fact, the parties in hearing have a pivotal role during the proceedings, while the court's role is relatively passive, and limited essentially in determining the conflict between them. ${ }^{46}$ This adversarial approach applies to both civil and criminal hearings. The principle of parties' control of litigation proceedings is being widely used in civil litigation, even when government or state is one of the parties. In civil cases,

45 Roscoe Pound claims that anglo-american legal system is plagued with an 'individualist spirit' a focus on litigation as a 'game'. See generally Roscoe Pound, 'The Causes of Popular Dissatisfaction with the Administration of Justice' in Kathleen M. Sampson (ed) Handbook for Judges (2004).

46 Laura Nader, 'Controlling Processes in the Practice of Law: Hierarchy and Pacification in the Movement to Re-Form Dispute Ideology’ (1993) 9 Ohio St. Journal on Dispute Resolution 1, 5-6. 
government gladly engages in negotiation with the private party for outer court settlement. The practice of government involvement in negotiation with the private party is not a new phenomenon in the system of adversarial justice. If it is so, why can the prosecution not engage in negotiation with the accused? There are no justifications against positive answer of this question.

b. Within the framework of this fundamental principle, usage of informal mechanisms to settle the case seems very much amenable. Under this principle, the parties are allowed to take decisions independent of court on some issues of claims and possible liabilities. ${ }^{47}$ In such case, the court takes obligation to execute the decision reached by the parties. The legal sanction of such agreement is fully established by laws. The autonomy granted to the parties will definitely contribute to the speedy trial, the success of prosecution and the timely meaningful and reparation of the harms sustained by victims of crimes.

c. In civil jurisdiction, the disputed is litigated between plaintiff and defendant or respondent and the role of court is to determine the truth or legitimacy of their arguments. In criminal trial, the prosecution and the accused are the parties to the conflict. The court, on the other hand, hears the pleas of the prosecution and determines the strengths of evidence supplied by him/her beyond reasonable doubt. In this process, there are some important principles or rules to be followed: a) the hearing should take place in presence of the both parties as a mandatory rule; b) each party must supply information to the other regarding its motions; c) the accuser must prove the allegation with the strength of evidence, and d) each party has to justify its argument or plea on the strength of evidence. The rules laid down by these principles plainly show that none of the parties singularly have any significance within the framework of the adversarial model. These principles or rules imply that the parties in the criminal proceedings are treated on equal footing; hence the State cannot claim a special privilege against the accused. Hence, the prospect of negotiation between the parties in criminal proceedings is not ruled out. ${ }^{48}$

d. In the civil suit, the State may sue or be sued and cannot be treated differently to the private party which is true for criminal proceeding, as well. In both the suits, hearing of the cases do not grant a legal ascendency to one or other party. In civil matters the the principle of equal footing in hearing grants privileges to the parties to engage in outer court negotiations for settlement of all or some issues within the framework of law. The outer court settlement mechanisms include arbitration, mediation, negotiation and conciliation. The use of these alternative methods of conflict resolution in many instances has the effect of transferring the burden of finding a resolution to the impasse to the

\footnotetext{
$47 \quad$ See Gabriel Hallevy (n 42) 5.
}

48 Ibid. 
parties themselves. ${ }^{49}$ Similar practice can be developed in criminal suits by the application of 'plea bargains' which is an alternative to conducting a full criminal trial by offering a solution to the conflict in court, which in a broader sense imbibes the idea of alternative dispute resolution. Therefore, plea bargaining is a suitable example to illustrate that application of informal mechanism in the criminal jurisdiction is possible. ${ }^{50}$

\section{Justifications for Incorporating Informal Mechanisms of Dispute Resolutions in Criminal Proceeding}

It can be safely argued that the credibility of, and confidence on criminal justice system can significantly be enhanced by ensuring application of alternative dispute resolutions mechanisms within the framework of aforementioned contentions. To expound further on justifications, following arguments are provided:

a. Informal justice system is a non-state dispute resolution mechanism falling outside the ambit of formal system. It is commonly practised in developing countries and those in transition. Empirical researches back the desirability ${ }^{51}$ and comprehensibility of the system. ${ }^{52}$

b. The formal system of criminal justice regards crime as matter of State's concern, and thus asserts exclusive power of prosecution. Within this framework, crime against victim is considered an offence against society or the State. As a matter of fact, victims of crimes have very restricted role assistant to the prosecution. Victims of crime are thus obliviously ignored. Victims have no 'say in prosecution at all'. This typical principle of formal criminal justice makes victims apathetic to the criminal procedure. In developing countries, the indifferent attitude of victims.

$49 \quad$ Nader (n 46) 6.

$50 \quad$ Hallevy (n 42) 6.

51 For instance, Raute and many minority indigenous communities in Nepal find it embarrassing to approach the court. In Mustang, the community of Thakali people has a court of their own presided by a group of elderly. The trial takes place in public. The parties can present witnesses for testimony. The judgment is awarded after an elaborate hearing. The judgment is fully respected by the parties as there is a strong social pressure behind the judgment. The government institutions often take no cognizance of cases from such communities because the enforcement of judgment without approval of the elder leaders of the community is virtually impossible. Hence, the government institutions tacitly allow the community to settle disputes, expect those which involve heinous crimes like murder, robbery etc. For last some years, some institutions have taken initiatives to provide skill training of mediation to leaders of the community. In the community of Raute, which is still a nomadic community, no interference of any type from the Government is acceptable. The community has its own chief who has the jurisdiction to try all civil and criminal cases. Not a single case from this community has reached to the formal system as of now. The rate of crime, due to stronger social sanction and societal security system is negligible in these communities. Occasional incidents of violence also effectively dealt with by the societal mechanism. See generally Johan Reinhard, 'The Raute: Notes on a Nomadic Hunting and Gathering Tribe of Nepal 1974' (THLIB) < www.thlib.org/static/reprints/kailash/kailash_02_04_01.pdf> accessed 28 April 2013.

Ibid. 
c. In ethnically diverse developing countries, the minorities and marginalized groups generally tend to refuse accepting the legitimacy of the formal system of criminal justice as it has been regarded as an instrument of suppression of dominant group. The propensity to have a self-controlled system is higher among such communities. ${ }^{53}$

d. Alternative forms of justice and conflict resolution promote more restorative solutions. ${ }^{54}$ The demand for informal criminal justice has its roots in the penal law abolitionist movement, according to which the parties of disputes must resolve conflicts through mediation, conciliation and substitute prison and other forms of social control. ${ }^{55}$

e. The formal system divides the society as 'the victor and the defeated'. The informal system of justice believes on conciliation in the spirit to resolve the conflict and foster social cohesion. ${ }^{56}$

Minimization of risks of abuse of power, exploitation and discrimination: Informal justice system is not without risks of its own. These risks are mainly associated with abuse of power by people involved in non-state or informal mechanisms. But given the undeniable desirability of the mechanism, following measures are perennial in order to minimize, if not eliminate the potent risks:

a. The elites of the society may exploit informal justice mechanism to engorge their power structure and use it as an oppressive tool. ${ }^{57}$ It may equally be used by one as a tool for taking revenge against other. ${ }^{58}$

b. The informal or non-state mechanisms may encourage non-compliance of international human rights standards or instruments. The torture and inhuman treatment may be resorted to by the actors of the system as a means of 'quick and appropriate' sanction for violation of laws. ${ }^{59}$

c. The potential offenders may not be deterred by simplicity of the informal or non-state mechanism of dispute resolution. This may induce increment in rate of crimes.

\footnotetext{
53 Pedram, Birol \& Ri Junior (n 23).

54 Ibid.

55 Ibid.

56 E. Wojkowska, 'Doing justice: how informal justice systems can contribute?' (United Nations Development Programme and Oslo Governance Centre Disponível, 2006)

<http://www.undp.org/oslocentre/docs07/DoingJusticeEwaWojkowska130307.pdf. Vistied on 20> accessed 30 October 2012.

57 The Liason Office (n 44).

58 The community mediation has been a successful instrument of dispute settlement in Nepal. A study conducted by CeLRRd recently in some sample districts (Dang, Udaipur and Morang) shows that paralegal committees responsible for community mediation frequently harass males (husbands) upon complaints from their wives. In Nepalese society, the violence against women is still a serious problem. So when women get such platform, the biasness may burst out. The mediators predominantly women act in prejudice. CeLRRd (2011) (Unpublished Report).

59 The Liason Office (n 44).
} 
d. The risk of informal or non-state mechanism of dispute resolution being controlled by clandestine or unseen, or criminal groups and use of violence to execute the awards are not ruled out. ${ }^{60}$ In South Africa, for instance, vigilantes arrest suspects and summarily try them on streets and punish cruelly by flogging, stoning, beating and even burning. ${ }^{61}$

e. Religious, communal and social discrimination may be institutionalized. The informal systems may be emphatically exploited by the local religious and ethnic leaders, or by local landlords. Women, religious and ethnic minorities and immigrants might be subjected to discrimination. ${ }^{62}$

f. Retribution may become the favoured philosophy of the informal trial. The obsession in retribution may perpetuate the cause of conflict, and the entire society may be divided between 'contesters'. Historically, most non-state or informal systems are found using 'retribution' as a guiding philosophy of the punishment. In traditional developing societies, the immediate revenge may be taken as most 'effective and reliable form of justice'.

\section{Possible Models of Informal Mechanisms in Criminal Justice}

The abovementioned problems not formidable and non-addressable. Conscious, informed and systematically planed schemes can control or remove those risks and make informal mechanism works efficiently and effectively in criminal justice systems. Hence, societies are to be prepared to depart from conventionality of the system of criminal justice. For this, governments and civil societies should be prepared to give up believes that: a) criminal justice system is the state's monopolized punitive instrument; b) the philosophy of criminal justice system is founded on healing of offence only by legitimized revenge to the offender; c) punishment is the only justice and d) punishment to the accused will end the conflict engendered by the crime. The following modality on the informal criminal justice mechanisms is suggested:

$60 \quad$ Pedra, Birol \& Ri Junior (n 23) 60.

61 W. Scharf, 'Non-State Justice Systems in Southern Africa: How should Governments Respond' (Governance and Social Development Resource Centre) <http://www.gsdrc.org/go/topicguides/justice/non-statejustice- and-security-systems> accessed 21 October 2012.

62 Informal justice mechanisms pose many risks to women and girl victims of violence. However, there is general consensus that simply outlawing practices or mechanisms without public education and awareness is the least effective means of reform in the informal sector. Changing the law in combination with ongoing education and provision of alternatives is a preferable strategy. UN WOMEN, 'Informal Justice Mechanisms' (UN Women, 2009)

<www.endavwnow.org/en/articles/881-informal-justice-mechanisms.htm> accessed 28 April 2013. 


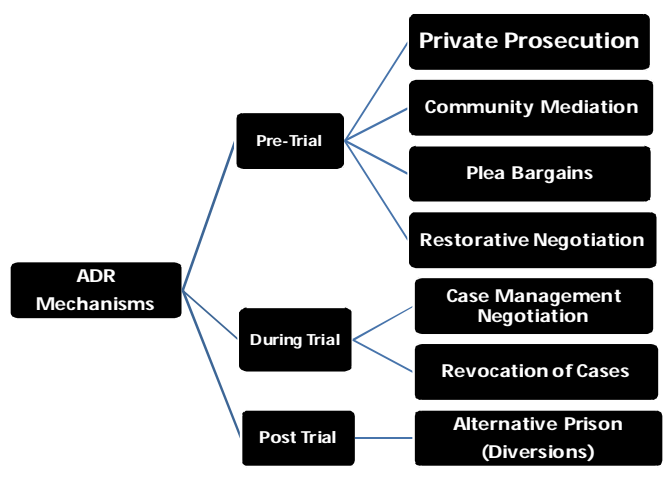

The above diagram above depicts the overall possibility of interposing informal justice mechanism in criminal justice framework. One fundamental principle worth consideration is that total substitution of formal system, except some petty criminal cases, by informal mechanisms seems impossible. One should therefore plainly understand that informal criminal justice system means nothing more than an idea of interposing possible mechanisms within the available framework of the criminal justice system for resolving a series of problems that are hindering 'the course of access to fair, impartial and speedy justice to the bulk of people in a given society.

Different mechanisms in different stages of the criminal proceeding is an effective approach. But before proceeding to discuss on the proposed framework, it is relevant to ponder upon some important guiding principles:

a. No informal mechanism should be allowed to take place before the crime is duly brought to the notice of the formal authority, i.e. the police, prosecutor or magistrate as required by the law of the given society. This requirement is considered important to reduce the abuse of mechanism by actors involved in the process.

b. The victim ought to be given autonomy to make a choice between the formal or informal mechanism when such is in option. To help the victim make a reasonable or appropriate informed decision, the authority of formal system must ensure a system of properly briefing about the available mechanism. ${ }^{63}$

63 In Nepal, for instance, a person having his/her civil claims filed before the court should consult the 'mediation counselling office' installed in all trail courts. Once the response of the counter party is received by the court, parties are called by a sitting judge in the mediation counselling and information concerning the 'procedure applicable in the case is given' and in the meantime they are urged to seek outer court settlement my mediation. Legal counsels of the parties accompany and participate in the discussion. The trial judge enjoys discretion of calling the parties jointly and individually with a view to prepare them for settling the disputes by mediation. However, no pressure or mandatory requirement is made. The same practice is aptly applicable in criminal cases, provided that it is fit to be resolved by means of informal mechanism. 'Success Story: Revitalizing the relationship distorted since 20 years' (AccesstoJustice, July 15 2012) < http://a2j.org.np/story_id=2> accessed 28 April 2013. 
c. The State, by law itself, must clearly enlist some cases, the high felonies for instance, as not applicable, except some exception plea barging and case management models under strict guidance of the trail court, for settlement by informal mechanisms. This guideline is important for countries in transition and newly emerged democracies. The susceptibility of decriminalization of human rights violation cases, such as forced disappearance, torture, murder for political revenge, kidnapping and so on the one hand criminalization of politics on the other hand in new democracies with acute transition is a serious problem.

d. The State, by law itself, must enlist the categories of cases that are open for resolution by means of one or other informal mechanism.

e. Institutions or individuals purporting to engage in informal criminal justice system as facilitator or mediator must have fairly good knowledge of criminology, penology and international human rights instruments or standards. The safeguard of human rights in criminal justice, unlike in civil disputes, is always a sensitive issue. No system of justice can compromise on internationally accepted rules of human rights.

f. The State should also make legal provision on review of the award achieved by informal justice mechanism. The appellate court can review such rewards by employing less formal proceeding, such as conference, instead of formal regulated hearing.

These safeguards are purported to avoid risks attached to the informal or non-state mechanism of criminal justice system. With these safeguard properly installed in operation, any society can embark upon providing for above-mentioned mechanisms in work. The basic legal ground work and philosophy for informal criminal justice system is readily available in constitutions of countries, at least those having democratic structure of governance. Most countries in the world today have unequivocally accepted that the rights to unrestricted and unhindered access to justice, speedy trial and the good governance. ${ }^{64}$ Moreover, there is a significant volume of international human rights laws which spectacularly calls for speedy trial as a fundamental right of individual. ${ }^{65}$

Private prosecution: Private prosecution may be an effective alternative mechanism for formal prosecution. It may be a suitable alternative to the criminal prosecution since it involves satisfaction of victims of crimes. Nepal has been traditionally practicing this modality with considerable success. The principle involved in this modality is that party or victim has autonomy to determine if the act of crime is a breach of peace against the entire

\footnotetext{
64 See generally Sayantan Gupta, 'Alternative Criminal Dispute Resolution System: An Evolving Interface in India’ (Abstract, SSRN) <http://ssrn.com/abstract=1461375> accessed 28 April 2013.

65 'Fifty Four Years in Jail without Trial: The Plight Prison Inmates in India' (Asian Human Rights Commission, 2004) <www.countercurrents.org/hr-zora260805.htm> accessed 28 April 2013.
} 
society or he/she alone. If the victim considers the violation is a serious breach of peace, he/she approaches state's mechanism with information of crime else resort to private prosecution. In Nepal this practice is categorised as private crimes. The private crimes on convictions involve imprisonment as well as pecuniary penalty. Most importantly, a crime prosecuted by the State in absence of evidence may be diverted to private prosecution. The State then comes out of the criminal proceeding. In Nepal petty criminal acts do not enter the criminal proceedings. Private prosecution is a good solution to manage the congestion as well as protect the autonomy of decisions that victims of crimes possess.

\section{Community Mediation as the First Step of Informal Criminal Justice System}

Community mediation is not purported to be a structure, it rather a principle. It implies that a group of community members can take cognizance of crime subject to provisions of law ( as provided in guidelines above) and can engage victim and offender in negotiation. The group of community members engaged in mediation process can have some structured framework of shape. Some structures being used in different parts of the world are enumerated in what follows:

Paralegal Committee in Nepal: Paralegal committees are successfully functioning in Nepal. They are trained on mediation process and some sort of psychology of dispute. The committee has a larger membership but only few, generally three peoples, are involved in mediation process. The committee maintains a close observation about the process and provides a significant strength to ensure enforcement of the agreement reached between two parties. The committee maintains the list of mediators and publishes the list of trained mediators at local governance office and district court. The local governance office and court often refer cases to the mediators or invite them to aid in conducting mediation. Paralegal committees' role is found to be successful in petty criminal cases or domestic violence. The skills of counselling they apply to prepare parties to mediate are found the strongest factor behind their success. There are currently 450 paralegal committees across Nepal, whose role in protection of children and women against all forms of violence is prominent. CeLRRd, in cooperation with UNICEF-Nepal, pioneered to establish paralegal committees in mid 1995 which were subsequently taken over by the Government by adopting a regulation. ${ }^{66}$

Shalis Kendra: Shalis Kendra is a mediation/arbitration board which is assembled by a group of people from village comprising of village elders, leaders (such as religious priests), retired civil and military officers, social workers and school teachers. The board has two roles - mediation of disputes and village court. The mediation panel consists of a group of people elected by parties and those nominated by Shalis Kendra Board. In the

66 'UNICEF-Real- Lives-Paralegal Committees' (UNICEF) <www.unicef.org/Nepal/5474-5519.htm> accessed 28 April 2013. 
village court, there are paralegals or lawyers. The village courts adopt a summary trial of cases exactly in line of the formal courts. The fundamental objective of the Shalis Kendra is to promote justice at grass root level by strengthening and activating billage court and Arbitration Council within the Union Parishad (a village governance committee) The group of stakeholders includes communities, community organisations, traditional leaders, religious leaders, local and national government authorities, organizations and institutions and local NGOs. These groups have diverse roles and responsibilities on making informal judicial system accessible to the disadvantaged women at rural areas. Stakeholders are categorized as Primary Stakeholders comprised of village people, especially women, children, minority groups, Chairperson of the Union paraishad, secretary, members and CBO members and Secondary Stakeholders comprised of women leaders, village leaders and social workers, religious leaders, household women leaders retired government officers, journalists and NGO Workers. Both the mediation board and village court take cognizance of petty criminal and civil cases. This has been a tremendously successful system in Bangladesh. There are 56 Shalis Kendra function only under Madaripur Legal Aid Association. Satisfaction of people in dispute resolution is a remarkable feature of this model. However, the awards of these mechanisms are persuasive. ${ }^{67}$

Lok Adalat (People's Court): Lok Adalat is a popular forum for access to justice. It is organized regularly with the help of university law schools in which professors and lawyers work as judges and students as volunteers. The venue of the court is generally fixed at place like university law school's premise. This court is modelled in line with the private tribunals in middle age in India. However, currently the lok adalat is perfectly legalized with a given jurisdiction. India has a long practice of settling disputes through media of elder people. The Lok Adalat was developed in the lights of historical experiences, being highly inspired by principles of Mahatma Gandhi. It is non-adversarial nature whereby mock courts are organized by State Authority, District Authority, Supreme Court Legal Service Committee, High Court Legal Service Committee and Taluk Legal Service Committee. The Lok Adalat deals variety of cases namely the 'civil cases of all types, matrimonial disputes, land disputes, labour disputes, and most importantly compoundable criminal cases.' It has been a widely successful alternative dispute resolution venture in India. $^{68}$

67 MLAA (Madaripur Legal Aid Association), 'Enhancing opportunity to justice at rural level' <www.malabd.org/core.html>; See also Belal Husain Joy (editorial), 'Court of Conscience-A Bangladesh Model of Mediation Mechanism (part I)' Daily Sun, Monday 23 May 2011.

68 See 'Lok Adalat Mechanism' (Andhra Pradesh State Legal Authority 2010)

<http://apslsa.ap.nic.in/local_adalat_mechanism.html> accessed 28 April 2013. 


\section{Community Mediation and its Role in Criminal Justice System}

Varieties of such systems as described above can be installed to deal with petty criminal cases at grassroots level, which otherwise cause a serious congestion at courts of first instance. Such mechanisms can successfully handle conflicts or violence at family level. The matrimonial violence, minor scuffles between people in neighbourhood, minor violence associated with public amenities, alcoholism-related disturbances and similar public nuisances such as eve teasing, dislocation or destruction of public information and notice system (such as vandalizing notice board related to traffic rules and street directions) and loitering of public places can be disputes to be effectively handled by community mediation

\section{Negotiation in Criminal Charges and Punishment through Plea Bargains}

Plea bargaining has traditionally been a system of negotiation between the prosecution and the accused, but in the recent past it has increasingly become a part of modus operandi in easier and successful disposal of the criminal cases. ${ }^{69}$ Plea bargains involve extensive negotiation between the prosecutor and the accused in various stages of criminal proceeding. Such negotiation generally includes: a) bargaining for charges; b) intensity of charges and c) number of prosecutions. The prosecutors, however, have the authority to independently determine in the matters. But they may face challenges of having evidences to confirm charges or time limitations to achieve exactly what has been intended. In such a situation, prosecutors offer choices for the accused to accept the crime and reduce their punishment and face less charges or face a trial with most stringent punishment if proven. In lieu of this concession offered by the prosecutor, the accused may agree to this limitations thereby cooperating to the conviction motion by admitting the charge. Obviously, the mechanism of plea bargains can serve the objective of relieving the prosecutor's burden of proof that is a challenging job in the adversarial framework of criminal justice.

With this advantage, plea bargaining, through its appropriate extension and effective use, can serve as a mechanism of out of court resolution of conflict in criminal justice system. Within its extended framework, it can be used by parties to privatize the criminal proceeding by transferring it to their own private domain. ${ }^{70}$ Implicitly, the mechanism is already an alternative for conducting a full criminal trial in courts. The suggestions are:

a. The prevailing criminal justice system modalities or frameworks can suitably modify the plea bargaining mechanism from exclusive privilege of the prosecutor into an outer court negotiation mechanism between the prosecutor and the accused with a

\footnotetext{
69 Joseph A. Coquitt, 'Ad Hoc Plea Bargaining' (2001) 75 Tul Law Review 695, 696; Samuel R. Gross, 'The Risks of Death: Why Erroneous Convictions Are Common in Capital Cases' (1996) 44 Buff Law Review 469, 487.

70 Hallevy, (n 41) 6.
} 
view to accommodate victims' concerns of reparation or rehabilitation. The accused may agree to the reparation claims of the victim and the prosecutor may, for that consideration, agree to grant concession to the accused by limiting its demand in the sentence to be imposed, thereby levying more lenient punishment than the maximum one as required by laws in question. ${ }^{71}$

b. The defence counsel may be a responsible person for brokering system of interaction within the framework of plea bargaining negotiation between the parties including prosecution, the victim and the accused. The general structure of the mediation in plea bargaining is negotiation between the accused and prosecution, but to make it meaningful the involvement of defence lawyer as a mediator, for all intents and purposes, is crucial for the success of negotiation. Hence, the plea bargains can be transformed into form of mediation by agreement of the parties to negotiate and the preparedness of the defence lawyer to mediate. $^{72}$

c. Freedom to consent for contract and right to self-determination provide legal force to agreement concluded by the parties which is a general and simple principle of justice. The mechanism of plea bargaining, by virtue of informed consent between the parties, assumes the character of the contract thereby obtains recognition of the law.

Apparently, the prospect of remodelling the criminal justice system by modification of the mechanism of plea bargains into a system of engaged negotiation between prosecutors and the accused through media of the defence lawyer is plainly established. This approach is comfortably applicable even without wider change in the system of criminal procedure. The approach would be highly acceptable to the community because it would give a space for victims to bargain and settle their restorative claims by their involvement in the pre-trial stage.

\section{Restorative Negotiation}

Generally speaking, the restorative negotiation mechanism is reconciliatory or healingdriven model. It focuses on reinstitution or restitution of the broken and destroyed relationship between the victim of crimes and the accused which often may drive the parties or their families to the state of vengeance upon one another. The restorative negotiation model provides reparation to the victim of crime and solace from vengeance and criminal stigma to the accused. This is why the 'model is often defined as healing mechanism'. ${ }^{73}$ In this model, the community play a crucial role in brokering the negations between the victims of crime and the accused. Obviously, there are three stakeholders involved in this

71 See generally Anne M. Heinz \& Wayne A. Kerstetter, 'Pretrial Settlement Conference: Evaluation of a Reform in Plea Bargaining' (1979)13 Law \& Society Review 349.

72 See generally Brandon J. Lester, 'System Failure: The Case for Supplanting Negotiation with Mediation in Plea Bargaining', (2005) 20 Ohio St. Journal on Dispute Resolution 563.

73 Mark William Bakker, 'Repairing the Breach and Reconciling the Discordant: Mediation in the Criminal Justice System’ (1994) 72 N C L Review 1479, 1486. 
model', whereas the role of the prosecutor and the defence lawyers is also important to create an 'environment conducive to negations'.

Restorative mechanism is the most wanted and legitimate response to crime. It assures the role of victim in the dispute settlement and offenders are encouraged to assume responsibility for their criminal acts, such as by apologizing, returning the stolen property, paying compensation or doing community service. As rightly pointed out by Glaser, restorative justice helps in minimizing the menace of recidivism' ${ }^{74}$ Having discussed on the theoretical justifications, it is urged that criminal justice system avail itself by incorporating the following mechanisms of restorative justice:

a. Accepting and giving due place to the participation of victims of crimes in all affairs of pre-trial stage, including participation in the dialogue through representative of the community in the scheme of compensation to the harms committed.

b. Engaging mediation between the accused and prosecutor, for the better interest of victim's reparation, within framework of plea bargains.

c. Making state accountable to the harms of crimes sustained by victims since the crime has occurred not only by the offensive act of the offender but also due to failure of the State to ensure security in the society. Hence, the restorative justice scheme must enable victims of crimes to negotiate with the State authorities in order make the latter pay 'contingent or transitional reparation'. This mechanism would promote sincerity and efficiency of the State to the security requirement and, in the meantime, prevents escalation of conflict for the sake of revenge.

Restorative justice scheme can in this way be used as a synonym for mediation during the pre-trail stage. $^{75}$

\section{Case Management Mechanism}

Case management mechanism is a means of removing backlog and expediting the flow of case disposal. As mentioned earlier, the removal of the 'case-clogged situation' will reduce the cost of parties as well as the State. Moreover, it generates an atmosphere conducive for compliance of human rights standards. Implementation of the fast-track model is one preferred mechanism of the case management model. The fast-track model involves negotiations between the court and the parties as well as negotiations between the prosecution and the accused. The early and speedy disposal of the case in equally a matter of concerns of victims of crimes. Hence, the formal justice system must ensure place for 74 D. Glaser, Profitable Penalties: How to cut both Crime Rates and Costs (Pine Forge 1997) 269.
75 Anupam Sharma v. NCT of Delhi \& Anr 146 DLT 497 (Delhi High Court 2008). 
victims of crimes to engage themselves in negotiations with the court through prosecution. $^{76}$

\section{Revocation of Cases}

Revocation of cases is a mechanism of disposing criminal cases less significant from the viewpoint of gravity of harm and public interest. Mostly, the crimes involving the public interests without having immediate harms to individuals may be apt cases to revoke by the prosecution. The opinion of civil society may be a good guide in this respect. The payment of monetary penalty is emphatically focused in such cases. Corruption charge is a typical example, in which the offender is liable to pay the sum of corrupted amount and the penalty equivalent to. Payment of such fines and dues may be made a ground to revocation of the case or reduction of the sentence. It can be handled exactly like mediation through plea bargains. In Nepal, persons surrendering to the court after judgment, having sentenced by the court in charge of corruption, may obtain reduction of $20 \%$ in the imprisonment and the monetary penalty. The accused has right to negotiate with the court and agree to the offer provided by the law. The scheme of revocation of cases can also apply in respect of those offenders who have serving trial 'for traditional crimes such as killing of cows in Nepal, infanticide, and crimes committed in a provocative state.'

\section{Alternative Prison}

Penal Reform International has suggested the following approach in this regard:

Pre-trial diversion measures such as alternative dispute resolution and mediation should be fully exhausted before consideration of formal court proceedings. Moreover, diversion measures at all stages of the criminal justice process are vital. Given that police across the region are prone to over-arrest, arrest without substantial grounds must be avoided and alternatives such as a caution or fine fully utilised. Safeguards to limit the over-use of police and judicial custody require strengthening. Furthermore, revitalising and reinvigorating non-custodial measures including community service and other applicable methods is essential to prevent exposure of persons not considered a threat to society to hardened criminal behaviour in prison and the perpetual cycle of crime and re-offence". ${ }^{77}$

76 The experience of Nepal is noteworthy. In 2011, the District Court Regulation introduced a system of fast-track hearing' of cases upon request of the parties. This provision has implicitly empowered victims of crimes to approach prosecutors, i.e. state lawyers to expedite the trial and final hearing the case. The importance of fast-track mechanism lies on protection of evidence from being tampered by offenders or by lapses of time. It is therefore significant instrument to consider from the point of speedy trial and protection of the interests of victims of crimes.

77 Penal Reform International, Penal Reform Strategies in Asia and Pacific: The Experiences of Penal Reform International and Partners on Prison Reforms and Access to Justice (Penal Reform International 2003) 2. 


\section{Conclusion}

Countries across the world have inherited the criminal justice system as a legacy of the past. Most principles, theories and normative standards possessed by it emphasize the public nature of the crime and underestimate harms sustained by individuals. The criminal justice systems being practiced by both developed and developing countries are obsessively preoccupied by punitive aspects and mesmerized by powers of arrest, detention, interrogation, prosecution and conviction. These principles and theories have lost their legitimacy due to escalation of rate of crime growth rate in developed countries and the cancerous growth of corruption and inefficiency of justice machineries in the developing countries.

The transplantation of the system of criminal justice from colonizing countries is a culprit behind the failure of criminal justice machinery in the developing countries. Massive corruption and power abuse creeping inside the system have their roots in the colonial legacy. The notions and insights of the system are hardly articulated to the minds of people who suffer from chronic ignorance and illiteracy. Unfortunately and shamefully so, the institutions of criminal justice systems in most developing countries function in language not spoken or understood by the native population. As a matter of fact, neither is the procedure communicable nor is the information comprehensible. In this backdrop, one can legitimately argue that the criminal justice system in most of the developing countries is a dogmatist institution devised not for the benefit or access of people but for the decoration of the State.

Informal justice system is in place in many developing societies since time immemorial. While excessive traditionalism and static attributes make them vulnerable of being abused and used to institutionalise discrimination, the possibility of them being refined and modernized is certainly not ruled out. Reformed and modernised versions of multitude of informal systems can complement the formal system in many ways. They can contribute to 'remove clogging of the courts by petty cases, reduce the cost of administration of justice, provide easy and affordable access to justice, and most importantly can simplify the process of formal justice system. Hence, the use of informal system is not only desirable but inevitable in order to (a) institutionalize the enforcement of human rights standards and (b) prevent the miscarriage of justice.

The informal system can complement the formal system in two ways by: a) functioning side by side as an autonomous independent system, and b) getting inserted into the formal system. The community mediation is an autonomous institution aiming to reduce burden of the formal system and provide access to justice in affordable cost, whereas the mediation 
within the framework of plea bargains, restorative model and revocation of cases' are instruments to modify and modernize the formal system. These latter modalities would simplify the process of formal criminal justice and make it purposive. The state of victims of crimes would be fully ascertained and the normative standards would be changes. It is necessary to generate a movement of use of informal mechanisms for dispensation of the criminal justice system. Justice is a right of people; denied trading of justice is a right as well. Justice defends dignity and security of human being. Hence, no justice can be perceived in oblivion of development. Informal justice mechanisms are instruments to infuse justice with development endeavours.

$* * * * * * * * * * * * * * * * * * *$ 